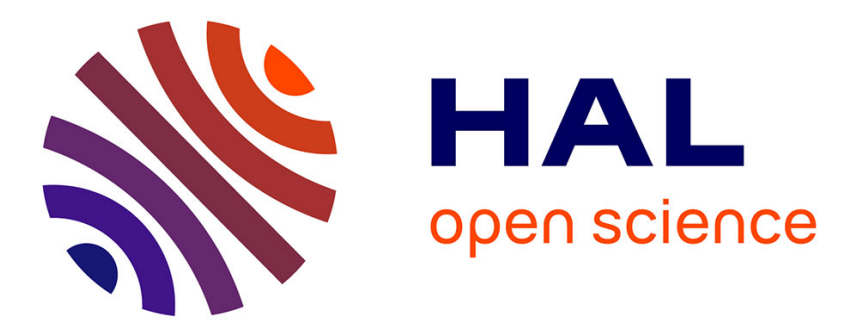

\title{
Recent progress on room temperature color center lasers and their applications for fluorescent kinetic spectroscopy

\author{
T. Basiev
}

\section{- To cite this version:}

T. Basiev. Recent progress on room temperature color center lasers and their applications for fluorescent kinetic spectroscopy. Journal de Physique IV Proceedings, 1994, 04 (C4), pp.C4-608-C4-608. 10.1051/jp4:19944158 . jpa-00252614

\section{HAL Id: jpa-00252614 https://hal.science/jpa-00252614}

Submitted on 1 Jan 1994

HAL is a multi-disciplinary open access archive for the deposit and dissemination of scientific research documents, whether they are published or not. The documents may come from teaching and research institutions in France or abroad, or from public or private research centers.
L'archive ouverte pluridisciplinaire HAL, est destinée au dépôt et à la diffusion de documents scientifiques de niveau recherche, publiés ou non, émanant des établissements d'enseignement et de recherche français ou étrangers, des laboratoires publics ou privés. 


\title{
Recent progress on room temperature color center lasers and their applications for fluorescent kinetic spectroscopy
}

\author{
T.T. BASIEV
}

General Physics Institute, Russian Academy of Sciences, Vavilov Street 38, Moscow 117942, Russia

Review on investigation and development of room-temperature stable color centers and tunable color center lasers will be done Different oscillation modes of color center crystals: cw, nanosecond, pico- and femtosecond will be discussed. Comparison of laser parameters of color center crystals with Ti-sapphire and Cr-doped laser crystals for tunable operation are under consideration.

Number of now available color center lasers with very wide spectral region of tuning in near IR and visible under single line, multiline or superbroadband mode of oscillations with the manual or PC computer scanning will be outlined.

Multiyear experience of applications of room-temperature color center lasers for time resolved fluorescent laser spectroscopy will be analized. Narrow band, short pulse, resonant laser excitation of rare earth ions metastable levels in crystals and glasses provide excellent starting point for precise studying multi exponential and nonexponential fluorescence decay due to direct cross relaxation energy transfer, migration-limited energy transfer or spectral-spatial migration on stochastic ensemble of ions. Developed technique and great number of results on exited state solid's dynamic form very good basis for development of new sensitizes, up-converters and high concentrated laser materials. 